Neither classical Marxism, which understands law as a consequence of larger structures and to be disrupted through the contradictions in the relationship between capital and labour, nor liberal theory of law, which understands law as an instrument or 'means to an end' ( $p$. 25) acknowledges agency in law.

\section{Human rights and the transformation of property}

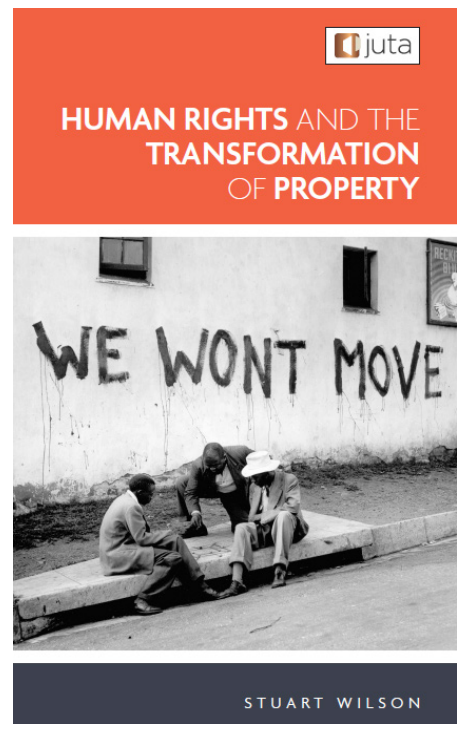

Title: Human rights and the transformation of property

Author: Stuart Wilson

Publisher: Juta and Co. (Pty) Ltd

ISBN: 9781485138228

Date: 2021

Research Field: Human rights

\section{Reviewed by Prof. Marie Huchzermeyer}

DOI: http://dx.doi.org/10.18820/2415-0495/trp79i1.9

Housing is one of the most prominent themes around which statutory urban policy intersects with human rights. Stuart Wilson's Human rights and the transformation of property examines this intersection through the tension that exists between the hierarchical common-law framing of property rights and the transformative reading of the right to access to adequate housing, as intended by the South African Constitution. Continuity in colonial and apartheid property law has entrenched inequality, as Wilson details in Chapter 3. However, post-apartheid housing rights litigation has chiselled away at the dominant common-law-informed reading of the property clause in the Constitution. Wilson demonstrates that this has created space for agency from below.

The overarching message of Wilson's book is that impoverished communities can, with legal support, craft case law that has far-reaching effects, also shaping and widening the spaces for such agency. In other words, the everyday struggles of impoverished communities, when involving court action that is embedded in 'legal strategies for social change' (p. 9), have interfered in how property law treats those for whom property ownership is out of reach, while opening up the possibility to further redefine the limits of property.

This 'agentic' value of law, Wilson argues, is not adequately acknowledged in theories of law, a critical review of which the book presents in Chapter 2.
The structure and agency approach to understanding human rights accepts a social role for human rights. Wilson takes this scholarship further, by examining three areas of South African property litigation from below. One relates to the occupation of land (Chapter 4), the second is the legal relationship between tenants and landlord (Chapter 5), and the third is that between debtor or mortgage-bond holder and creditor (Chapter 6). The three substantive chapters take the reader through a succession of judgements that refine and expand impoverished people's rights and agency.

For anyone concerned with the promotion of spatial justice, the book provides insight into reasons for continued injustice as well as pathways for incremental social change. Wilson writes from within. His roles as interdisciplinary scholar, legal researcher, strategist, and more recently advocate have enabled this book to be grounded in real-life accounts from the coalface of South African urban inequality. This renders the text accessible to students, educators, planners, and other built-environment professionals. Given the message of agency, it should also be read by the grassroots protagonists whose struggles inspire Wilson's work.

Prof. Marie Huchzermeyer, School of Architecture and Planning, University of the Witwatersrand, Private Bag 3, Wits 2050, Johannesburg, South Africa. Phone: +27-11-7177688, email: <marie.huchzermeyer@wits.ac.za>, ORCID: https://orcid.org/0000-0003-3209-5449 